\title{
FUNGAL BIODIVERSITY AT THE GRAVEYARD “GotTESACKER" IN HERRNHUT (UPPER LUSATIA, SAXONY)
}

\author{
Alexander Karich ${ }^{1}$; René Ullrich ${ }^{2}$; Martin Hofrichter ${ }^{3}$ \\ TU Dresden, International Institute Zittau, \\ Department of Bio- and Environmental Sciences, \\ Markt 23, 02763 Zittau, Germany \\ e-mail: ${ }^{1}$ alexander.karich@tu-dresden.de; ${ }^{2}$ rene.ullrich@tu-dresden.de; \\ 33artin.hofrichter@tu-dresden.de
}

\begin{abstract}
The Gottesacker ("God's acre") in Herrnhut (Upper Lusatia, Saxony) has been a graveyard for almost 300 years. G. ZSCHIESCHANG has mapped its fungal community since the 1960ies. Combining these findings and those of other mycologists, mycological data that cover about 55 years are reported here. In this context, we discuss the fungal biodiversity with special emphasis on CHEGD species (Clavariaceae-Hygrocybe-Entoloma-GeoglossaceaeDermoloma). These species are used to classify and assess the conservation value of grasslands by monitoring their fungal communities. According to the determined CHEGD profile, the Gottesacker graveyard is ranked as a grassland of international importance. In addition, we present macroscopic and microscopic characteristics of two rare CHEGD species: Entoloma brunneosericeum and Clavaria messapica. These are the first records of both species for Germany and Saxony, respectively.
\end{abstract}

\section{Keywords}

CHEGD; Clavaria messapica; Entoloma brunneosericeum; Hygrocybe; Biodiversity; Fungi.

\section{Introduction}

During the last decades, a serious loss of biodiversity has been recorded worldwide [1]. The human-driven loss of biological diversity has numerous causes, for example, pollution due to fossil fuels and crude oil-based chemicals and changes in land use including overgrazing, deforestation, urbanization and the cultivation of monocultures. Especially the latter is associated with the usage of biocides including fungicides as well as chemical fertilizers causing eutrophication. Grassland fungi are particularly affected by fertilization - not only through the direct application of fertilizers - but also via passive input through rain, surface water and wind. The so-called CHEGD species represent fungi that are highly sensitive to such inputs and are hence appropriate for biomonitoring purposes; the acronym stands for Clavariaceae-Hygrocybe-Entoloma-Geoglossaceae-Dermoloma [2]. It is thought that these praticolous fungal genera are well adapted to nutrient-poor environments because of their biotrophic [3, 4, 5] and/or endophytic (in higher plants) lifestyles [6]. Not least, this may explain why CHEGD fungi respond highly sensitive to external nutrient impact, which makes them suitable bioindicators for unimproved "natural" grasslands.

Because of intensive farming (industrial agriculture) in the German part of the Euroregion "Neisse-Nisa-Nysa" during the last decades, only few locations of unimproved grasslands have remained, e.g. in the Zittau Mountains (Zittauer Gebirge) and the Upper Lusatian Heath and Pond Landscape (Niederlausitzer Heide- und Teichlandschaft). On the other hand, artificial man-made locations and landscapes, such as meadows in parks and cemeteries, can 
be low in nutrients as well, depending on horticulture management, and have an astonishing number of rare fungal grassland species [7]. Such an interesting locality is the graveyard Gottesacker ("God's acre") that has been situated on the Hutberg in Herrnhut ${ }^{1}$ (Saxony) since 1730. Remarkably, Herrnhut is renowned for three important mycologists. LUDWIG LEWIS DAVID VON SCHWEINITZ and JOHANN BAPTISTA VON ALBERTINI wrote the treatise "Conspectus fungorum in Lusatiae Superioris agro Niskiensi crescentium, e methodo Persooniana" in 1805 [8], describing 127 new fungal species. Further, in the early 1960s, the mycologist GERHARD ZSCHIESCHANG ${ }^{2}$ began an inventory of the funga of Saxony with a focus on East Saxony (Upper Lusatia), part of the Euroregion "Neisse-Nisa-Nysa", which included the Gottesacker graveyard in Herrnhut.

\section{$1 \quad$ Research Subject}

Since 2016, the authors of this article have been regularly surveying the Gottesacker area to record the funga, with a special focus on CHEGD species. Our results and findings are presented in tabular form and discussed in terms of the available data. Remarkable fungal species are described in detail, including their macroscopic and microscopic characteristics.

\section{$2 \quad$ Material and Methods}

\subsection{Locality}

The graveyard Gottesacker $\left(14^{\circ} 44^{\prime} 54,9^{\prime \prime} \mathrm{E} ; 51^{\circ} 1^{\prime} 13,68^{\prime \prime} \mathrm{N}\right)$ is about $40,000 \mathrm{~m}^{2}$ in size and located in the eastern part of Herrnhut, a town in the Upper Lusatia region $25 \mathrm{~km}$ southwest of Görlitz and part of the "Lusatian Highlands" (German Lausitzer Bergland, Upper Sorbian Łužiske hory) at an altitude of about $350 \mathrm{~m}$. The geology of the region around Herrnhut includes granite in deeper layers and surface clay at the top, but the latter have been strongly influenced by human activities and cannot be ascribed in detail for the graveyard; thus, limerich and sandy sections cannot be excluded. The local climate ranges between oceanic and humid continental climate. Respective meteorological data recorded between 1961 and 1990 (station Herrnhut) were as follow: $688 \mathrm{~mm}$ average rainfall with maxima in August $(75 \mathrm{~mm})$ and average temperature $7.7{ }^{\circ} \mathrm{C}\left(-2.1^{\circ} \mathrm{C}\right.$ January to $16.6^{\circ} \mathrm{C}$ July). Unfortunately, for the last three decades, no climate data are available for Herrnhut. Ostritz, about $13 \mathrm{~km}$ east of Herrnhut, had an average rainfall of $636 \mathrm{~mm}$ (1991-2020) with its maximum in July (86 mm). In addition, with regard to temperature, we refer to data from Görlitz (1991-2020) with an average of $9.3{ }^{\circ} \mathrm{C}\left(-0.2{ }^{\circ} \mathrm{C}\right.$ January to $18.9^{\circ} \mathrm{C}$ July $)$.

\subsection{Morphological Studies}

Fresh specimen were studied with a light microscope (Zeiss Axio scope). Hand cut thin sections were examined microscopically by squash mounts. Fresh material was inspected in water. Dried material was re-examined in $5 \% \mathrm{KOH}$. Measurements of spores were taken from a spore print on stems of dried material (except for Clavariaceae). All other features where measured on re-hydrated material in $5 \% \mathrm{KOH}$. Measurements were conducted manually. Microscopic drawings are re-drawn in CorelDraw Graphics Suite from pictures taken with a Canon EOS 60D.

\footnotetext{
${ }^{1}$ The town Herrnhut was founded by Protestant religious refugees from Moravia ('Unity of the Brethren') under the patronage of NIKOLAUS LUDWIG GRAF VON ZINZENDORF in 1722.

$2 *$ 8. March 1931 in Bernsdorf; $\uparrow 7$. November 2012 in Herrnhut
} 


\subsection{DNA Extraction, Amplification and Sequencing}

DNA extraction was performed according to standard methods with the Plant DNA Mini Kit (VWR, peqlab). The ITS region (ITS1, 5.8S rRNA gene, ITS2) as well as parts of the 28S rRNA gene region were amplified by PCR using the standard primer pairs ITS4/5 and LR0/6 (White et al. [38]). PCR products were SANGER sequenced by LGC Genomics (Berlin, Germany). For comparison, sequences from the databases GenBank [9] and UNITE [10] were used.

\section{$3 \quad$ Results}

\subsection{List of Documented Species}

All recorded CHEGD taxa (including varieties and formae) are listed in Table 1 (based on the DgfM database [11] and own findings). The list includes all records made by ZsCHIESCHANG (his last entry, Entoloma chlybaeum var. lazulinum, dated 20 July 2008) and records made by other mycologists after his death, beginning with Cuphophyllus berkeleyi recorded by HARDKTE in 2015. The list of CHEGD taxa solely collected by ZsCHIESCHANG contains 38 and the overall list 50 species (compare Table 2). The species determination was done using morphological characters, unless otherwise specified in the article.

Tab. 1: List of CHEGD taxa (including subspecies and all recorded species of the genus Entoloma) reported for the "Gottesacker" graveyard in Herrnhut; records from 1964 until 2008 (Zschieschang) / records reported after 2008 until 2020, paragraph “\$” marks dubious records, asterisk “*” marks species regarded as grassland Entoloma spp.

\begin{tabular}{|c|c|c|c|}
\hline Taxon & Rec. & Taxon & Rec. \\
\hline Clavariaceae & & Entoloma Fr. ex P. Kumm. & \\
\hline Clavaria 1 & & ${ }^{*}$ E. anatinum (Lasch: Fr.) Donk & $0 / 1$ \\
\hline Clavaria L. & & ${ }^{*}$ E. asprellum (Fr.) Fayod & $0 / 1$ \\
\hline C. fragilis Holmsk.: Fr. & $2 / 0$ & ${ }^{\star}$ E. brunneosericeum Noordel., Vila, F. Caball. \& & $0 / 1$ \\
\hline C. messapica Agnello, Kautman. \& M. Carbone & $0 / 1$ & E. Suárez & \\
\hline & & ${ }^{*}$ E. chalybaeum (Fr.) Noordel. & $3 / 2$ \\
\hline Clavulinopsis Overeem & & ${ }^{*} E$. chalybaeum var. lazulinum (Fr.) Noordel. & $2 / 0$ \\
\hline C. corniculata (Schaeff.: Fr.) Corner & $4 / 1$ & E. clypeatum (L.) P. Kumm. & $1 / 0$ \\
\hline C. helvola (Pers.: Fr.) Corner & $1 / 3$ & ${ }^{\star}$ E. conferendum (Britzelm.) Noordel & $8 / 1$ \\
\hline C. laeticolor (Berk. \& M.A. Curtis) R.H. Petersen & $1 / 1$ & ${ }^{*} E$. dysthaloides Noordel. & $1 / 0$ \\
\hline C. Iuteoalba (Rea) Corner & $1 / 1$ & ${ }^{*}$ E. favrei Noordel. & $1 / 1^{\S}$ \\
\hline C. umbrinella (Sacc.) Corner & $0 / 1$ & ${ }^{\star} E$. infula (Fr.) Noordel. & $1 / 1$ \\
\hline & & E. juncinum (Kühner \& Romagn.) Noordel. & $1 / 0$ \\
\hline Ramariopsis (Donk) Corner & & ${ }^{*}$ E. jubatum (Fr.) P. Karst. & $0 / 1$ \\
\hline R. kunzei (Fr.) Corner & $1 / 1$ & ${ }^{\star} E$. sarcitulum (Orton) Noordel. & $0 / 1$ \\
\hline & & ${ }^{*}$ E. lepidissimum (Svrček) Noordel. & $0 / 1$ \\
\hline Hygrocybaceae & & E. lividoalbum (Kühner \& Romagn.) Kubička & $12 / 1$ \\
\hline & & ${ }^{*}$ E. lucidum (P.D. Orton) M.M. Moser & $1 / 0$ \\
\hline Cuphophyllus (Donk) Bon & & ${ }^{*}$ E. neglectum (Lasch: Fr.) M.M. Moser & $2 / 0$ \\
\hline C. angustifolius (Murrill) Bon & $1 / 0$ & ${ }^{\star} E$. nitens (Velen.) Noordel. & $6 / 0$ \\
\hline C. berkeleyi (P.D. Orton \& Watling) Bon & $0 / 2$ & ${ }^{*}$ E. papillatum (Bres.) Dennis & $13 / 2$ \\
\hline C. borealis (Peck) Bon & $1 / 0^{\S}$ & ${ }^{*}$ E. pleopodium (Bull.) Noordel. & $1 / 0$ \\
\hline C. cereopallidus (Clémençon) Bon & $1 / 0$ & ${ }^{*}$ E. porphyrophaeum (Fr.) P. Karst. & $7 / 0$ \\
\hline C. lacmus (Schumach.) Bon & $2 / 0$ & ${ }^{*}$ E. pseudoturci Noordel. & $0 / 1^{\S}$ \\
\hline C. pratensis (Pers.: Fr.) Bon & $16 / 5$ & E. rhodopolium (Fr.) P. Kumm. & $2 / 0$ \\
\hline C. virgineus (Wulfen) Kovalenko & $14 / 4$ & $\begin{array}{l}{ }^{*} \text { E. sericellum (Fr.) P. Kumm. } \\
{ }^{*} E \text {. sericeum (Bull. ex Mérat) Quél. }\end{array}$ & $\begin{array}{c}2 / 1 \\
12 / 4\end{array}$ \\
\hline Gliophorus Herink & & E. sordidulum (Kühner \& Romagn.) M.M. Moser & $2 / 0$ \\
\hline G. irrigatus (Pers.) A.M. Ainsw. \& P.M. Kirk & $12 / 1$ & E. tenellum (J. Favre) Noordel. & \\
\hline G. psittacinus (Schaeff.: Fr.) Herink & $9 / 3$ & ${ }^{\star} E$. undatum (Gillet) M.M. Moser & $1 / 0$ \\
\hline & & ${ }^{\star}$ E. velenovskyi Noordel. & $1 / 1$ \\
\hline Hygrocybe (Fr.) P. Kumm. & & E. vernum S. Lundell & $0 / 1$ \\
\hline H. ceracea (Wulfen: Fr.) P. Kumm. & $8 / 2$ & ${ }^{\star} E$. spec. undescribed species subg. Nolanea & $6 / 0$ \\
\hline H. coccinea (Schaeff.: Fr.) P. Kumm. & $16 / 2$ & & $0 / 1$ \\
\hline H. conica (Schaeff.) P. Kúmm. & $6 / 5$ & Geoglossaceae & \\
\hline H. conica f. pseudoconica (J.E. Lange) & $0 / 1$ & & \\
\hline H. glutinipes (J.E. Lange) R. Haller Aar. & $2 / 0$ & Glutinoglossum Hustad, A.N. Mill., Dentinger \& & \\
\hline H. insipida (J.E. Lange) M.M. Moser & $1 / 0$ & P.F. Cannon & \\
\hline
\end{tabular}




\begin{tabular}{|l|c|l|c|}
\hline H. persistens (Britzelm.) Singer & $4 / 0$ & G. glutinosum (Pers.) Hustad, A.N. Mill., & \\
H. quieta (Kühner) Singer & $2 / 0$ & Dentinger \& P.F. Cannon & $0 / 1$ \\
H. vitellina (Fr.) P. Karst. & $3 / 1$ & Dermoloma s.I. \\
Neohygrocybe Herink & $3 / 0$ & $\begin{array}{l}\text { Dermoloma J.E. Lange ex Herink } \\
\text { N. nitrata (Pers.) Kovalenko }\end{array}$ & \\
Entoloma s.I. & & & $5 / 3$ \\
Entocybe T.J. Baroni, V. Hofstetter \& Largent & & & \\
E. turbida (Fr.) T.J. Baroni, V. Hofst. \& Largent & $3 / 0$ & & \\
${ }^{*}$ E. vinacea (Scop.) T.J. Baroni, V. Hofst. \& Largent & $1 / 0$ & & \\
\hline
\end{tabular}

Source: Own and [11]
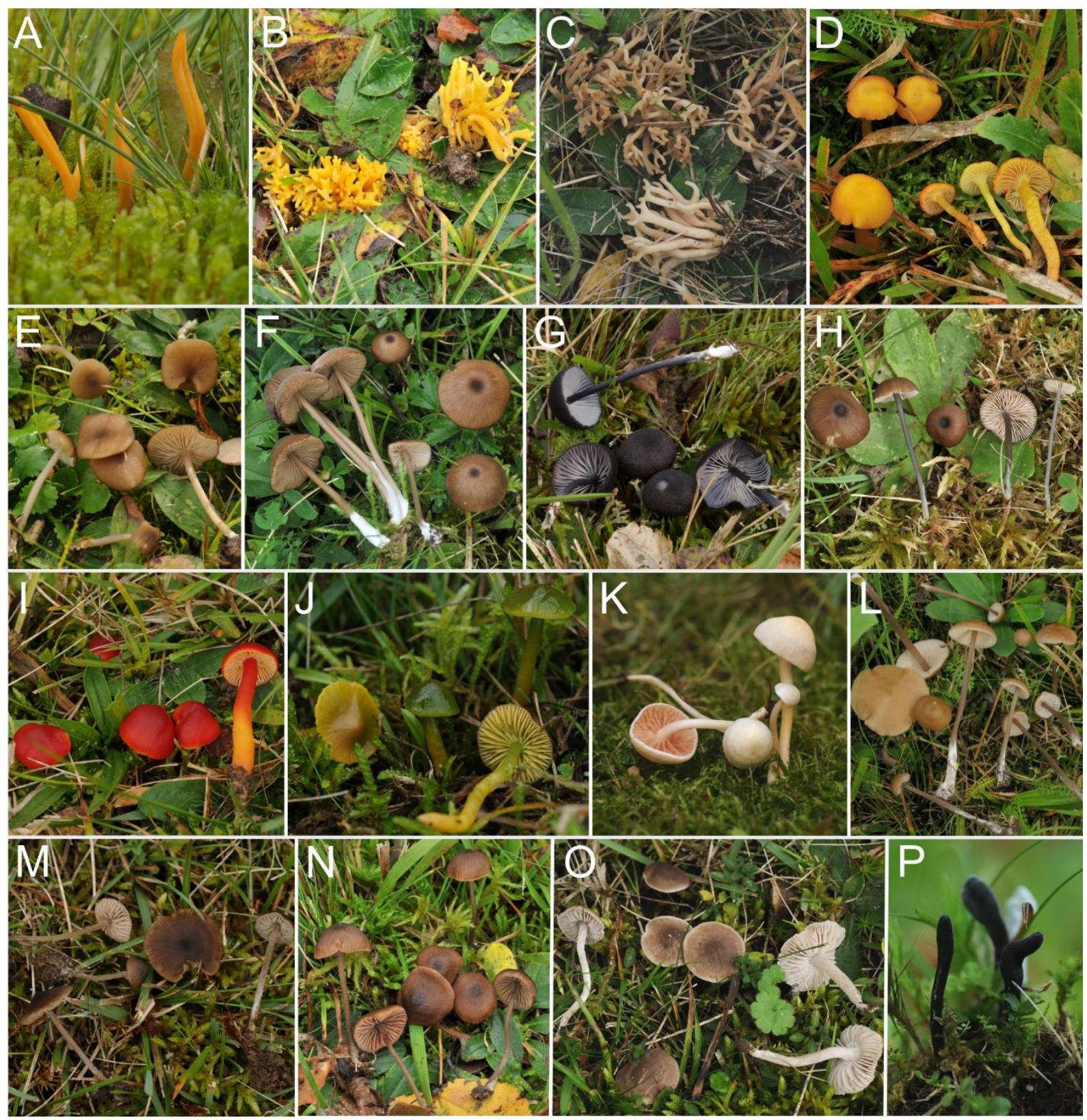

Source: All photographs taken from locality by A. Karich.

Fig. 1: Clavulinopsis luteoalba (A), Clavulinopsis corniculata (B), Clavulinopsis umbrinella (C), Hygrocybe ceracea (D), Entoloma pseudoturci (E), Entoloma sarcitulum (F), Entoloma chalybaeum (G), Entoloma asprellum (H), Hygrocybe coccinea (I), Gliophorus psittacinus (J), Entoloma sericellum (K), Entoloma infula (L), Entoloma papillatum (M), Entoloma favrei (N), Dermoloma cuneifolium (O) and Glutinoglossum glutinosum (P). 


\subsection{Description of Selected Species}

Two lately erected species were selected to be described in detail. These are to our knowledge the only descriptions next to their original diagnosis.

\subsubsection{Entoloma brunneosericeum Noordel., Vila, F. Caball. \& E. Suárez, Fungi non Delineati 66: 31 (2013)}

Pileus 9-27 $\mathrm{mm}$ in diameter, convex to applanate with a broad umbo, not to hardly striate at margin only, appearing waxy, not hygrophanous, almost uniformly dark brown (R: 70, G: 65, B: 45), margin slightly involute and sometimes with fine greyish-white fibrils.

Lamellae 22-30 with 1-5 lamellulae, crowded, emarginated to almost free, slightly ventricose, sordid greyish, lamellar edge concolorous. Smell inconspicuously farinaceous.

Stem 40-90 x 2-5 mm, overall densely silvery striate, hollow.

Spores (7-)8-8.4-9(-9.5) x (6.5-)7-7.65-8 $\mu \mathrm{m}, \mathrm{Q}=1.0-1.09-1.19$, mostly isodiametrical, only some slightly subisodiametrical, with 6 (7) rounded angles. Basidia 4-spored, 35-50 x 10-12 $\mu \mathrm{m}$.

Lamellar trama composed of long elements. Pileipellis, a cutis made of 5-10 $\mu \mathrm{m}$ wide hyphae, in subpellis up to $30 \mu \mathrm{m}$ wide, pigment abundant coarsely incrusted, brown, also infrequently intracellular (possibly vacuolar) brown, incrusted hyphae reaching into pileitrama. Hyphae in stipitipellis coarsely incrusted. Clamps restricted to hymenium only.

\section{Studied material:}

15.09.2017, Germany, Herrnhut, graveyard, in the meadow, MTB 4954.43, leg et. det. A. KARICH and R. ULLRICH, voucher No. IHI-17Ent01, ITS MW786739.

Comments: According to its original description, E. brunneosericeum is restricted to montane to subalpine Pinus forests [12]. Besides ours, another collection from an alpine pasture in Protomagno (Italy) [13], has already given indication for its preference of unimproved grasslands. However, the collection illustrated herein is the first one from a colline area and the first record of this species in Germany. The respective ITS sequence was found to be identical to the sequence of the holotype (JX454894).
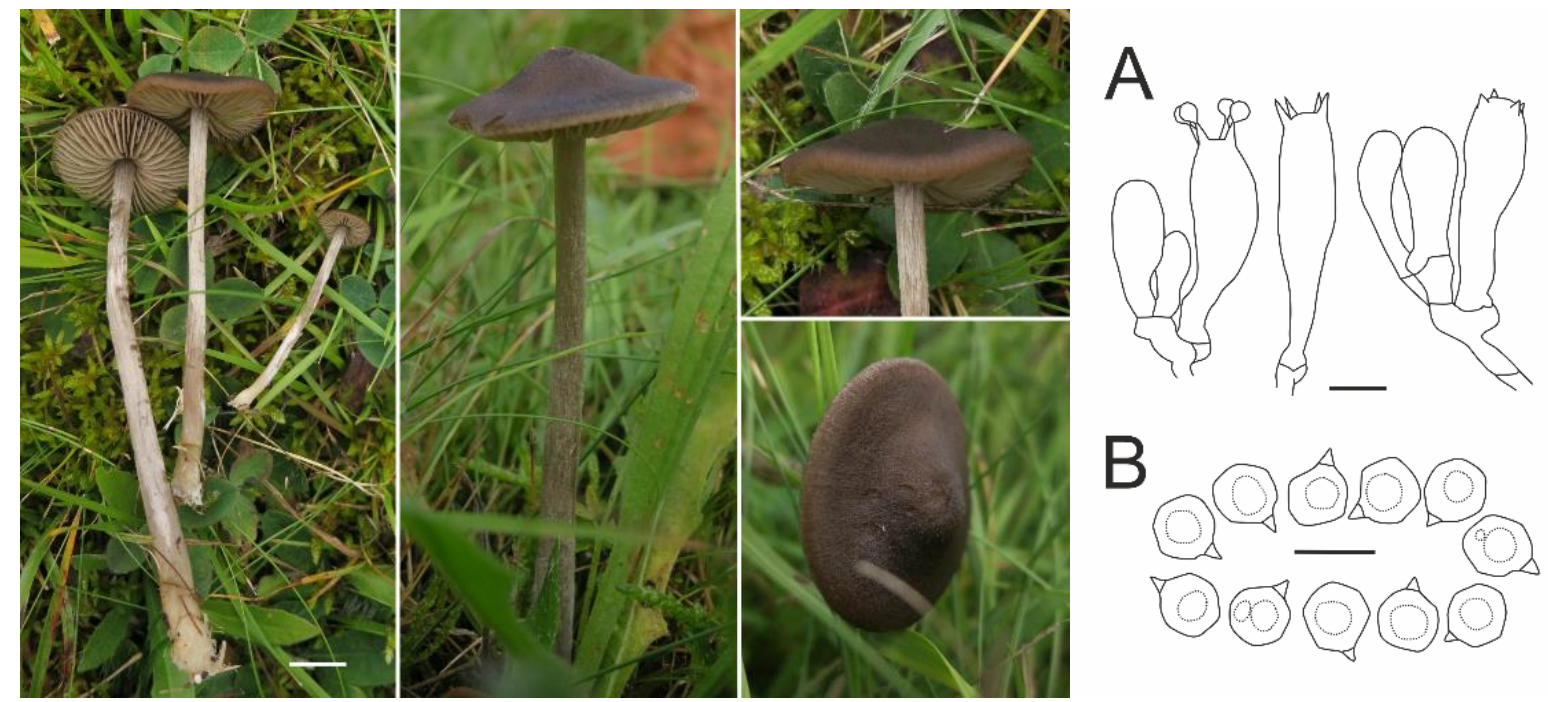

Source: Photographs and drawings by A. Karich.

Fig. 2: Entoloma brunneosericeum - macroscopic characters in situ (left, bar $=1 \mathrm{~cm})$ basidia (A) and spores (B), bars $10 \mu \mathrm{m}$. 


\subsubsection{Clavaria messapica Agnello, Kautman. \& M. Carbone, Rivista di Micologia 57 (3): 197 (2015)}

Basidiocarps clavate to cylindric-fusoid, slightly curved or twisted, tapering towards base, 40-70 mm x 2.5-5 mm, occasionally single branched, apex rounded, light rose colored, freezedried material white-rose, surface rugulose; sterile stem part slightly darker and only hardly distinguishable from fertile club, glabrous to finely pubescent. Flesh a little darker than surface and a bit crumbling. No significant smell or taste observed on fresh specimen, odor of dried material somewhat reminiscent of cocoa.

Spores (6-)6.5-7.0-7.5(-8) x 4- $\underline{4.3}-5 \mu \mathrm{m}, \mathrm{Q}=1.5-1.63-1.8$, heteromorphic cylindric, ellipsoid, ovoid, sometimes slightly phaseoliform or constricted, with an evident apiculus, not ornamented. Basidia 2- and 4-spored, 55-75(-80) x 6-9 $\mu \mathrm{m}$, long, slenderly clavate, often guttulate, at the base frequently with loop like clamp connections. Sterile, thin-walled cystidioid elements present in hymenium, $30-70$ x 2.5-6 $\mu \mathrm{m}$, cylindrical, curved, flexuouslytwisted to clavate, with rounded apex, with loop-like clamps. Trama consisting of cylindrical, 5-16 $\mu \mathrm{m}$ wide, clampless, thin-walled and rarely branched hyphae.

\section{Studied material:}

01.11.2020, Germany, Herrnhut, graveyard in the meadow, MTB 4954.43, leg et. det. A. KARICH and R. ULLRICH, voucher No. IHI-20Cla01, ITS MW786738, LSU MW786737.

Remarks: In the original description of $C$. messapica, AGNELLO ET AL. reported leptocystida to be present in the hymenium [14]. The authors here compared them with the fairly large cystidia of Alloclavaria purpurea (O.F. Müll.: Fr.) B. Dentinger \& D.J. McLaughlin, but on the other hand, they were mentioned to be much smaller than the basidia (30-55 x 3-5.5[6] $\mu \mathrm{m}$ ) and did not exceed the hymenium. In contrast, the photographs of micro characters in AGNELLO et al. [14] depict hyphae named cystidia that seem to be as long as the basidia. We observed many sterile cystidioid elements that could represent thin leptocystidia in the hymenium. However, these elements could be just as well transition states of young basidia (often referred to as basidioles, compare the discussion on Lamelloclavaria petersenii ADAMČ́́K \& BIRKEBAK in KARICH \& ULLRICH [15]). It should be noted that we did not observe any cystidioid element without loop-like clamps at the base. Of course, this raises the question of how the macroscopically similar $C$. incarnata and $C$. messapica can be distinguished morphologically, if the characteristic hymenialcystidia will not be present (or even if they are hardly to differentiate as such). As already mentioned by AGNELLO et al. [14], the spore size can be a good feature to discriminate between $C$. incarnata and $C$. messapica. The spores of the latter are never longer than $8 \mu \mathrm{m}$, while spores of $C$. incarnata may reach $10 \mu \mathrm{m}$ in length. Unfortunately, the variation of spore length of $C$. incarnata seems to include the spore size of $C$. messapica. This becomes clear when the spore measurements of $C$. incarnata in JÜLICH [16], KNUDSEN et al. [17] and CORNER [18] are taken into account. Thus, it can be assumed that specimen of $C$. messapica were misinterpreted in the past. Yet, AGNELLO et al. [14] mentioned that specimen of $C$. incarnata had turned yellowish when dried whereas those of $C$. messapica stayed rose without any shade of yellow. The basidiocarps of our (freeze-dried) collection faded a little to white-rose, not becoming yellowish. Another feature that is worth mentioning was the cocoa-like smell of dried specimen from Herrnhut, an odor that was not reported for $C$. incarnata so far. Nevertheless, the LSU sequence of the Herrnhut specimen is $99.52 \%$ identical to that of the type specimen of C. messapica (NG_068754). 

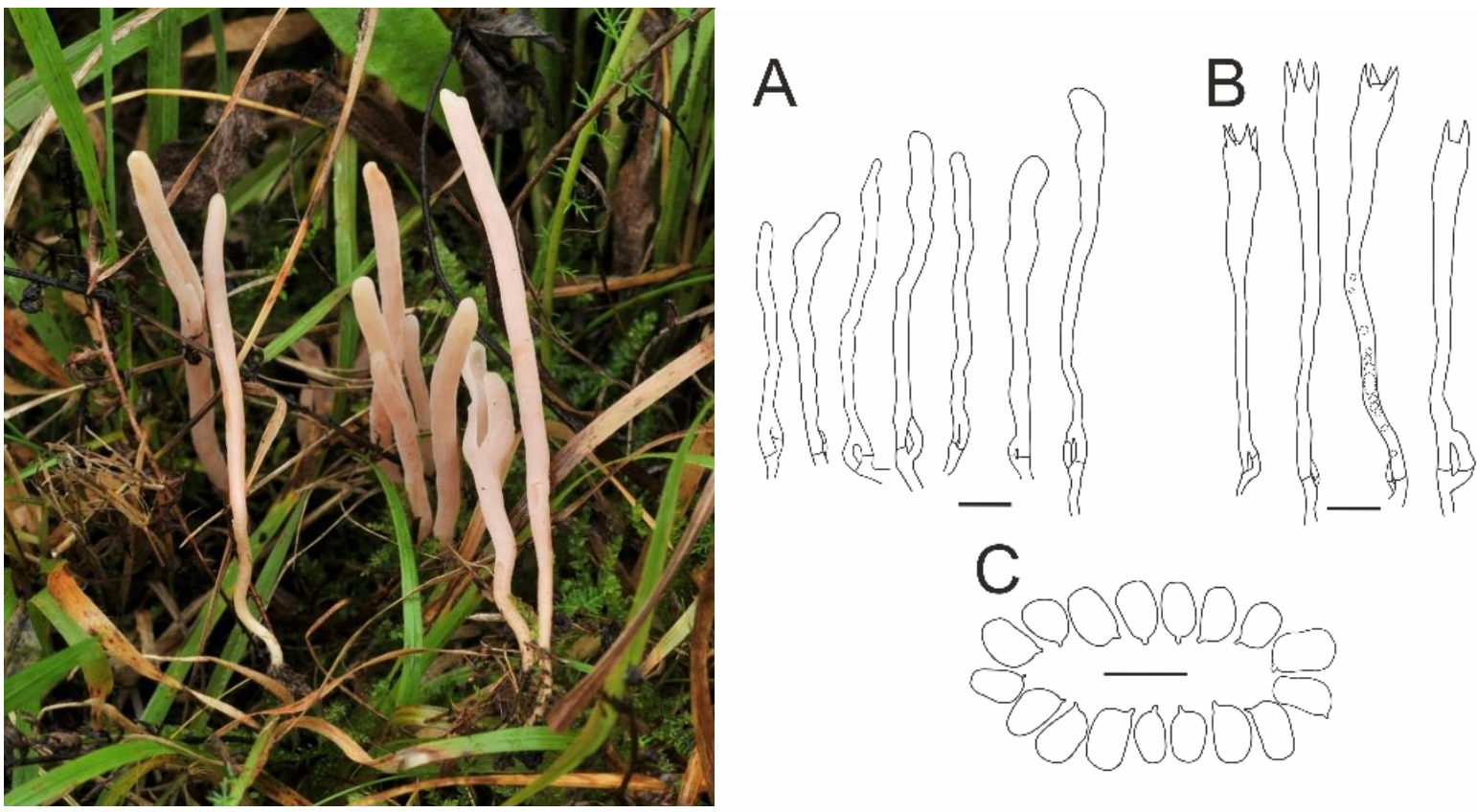

Source: Photograph and drawings by A. Karich.

Fig. 3: Clavaria messapica - macroscopic characters in situ (left) - basidioles (A), basidia (B) and spores (C), bars $10 \mu \mathrm{m}$.

\section{Discussion}

In addition to botanical (herbal) inventories, fungi surveys should be considered when determining whether grasslands are in need of protection. The relevance of CHEGD species for monitoring the conservation value of grasslands is indisputable [19-22]. The former concept of CHEG species of NITARE [20] and ROTHEROE [22] was extended by representatives of the genera Dermoloma and Camarophyllus as well by the single species Porpoloma metapodium (CHEGD) in GRIFFITH et al. [2]. With regard to species of the genus Entoloma, GRIFFITH et al. [2] excluded those that are listed as woodland dwellers according to LEGON \& HENRICI [23], and Rotheroe [22] included "grassland species of the family Entolomataceae" in his survey without further specifying the term. While it is reasonable to exclude species that certainly form ectomycorrhiza with Rosaceae, e.g. E. clypeatum, E. aprile and E. saepium [24, 25], the boundary between forest and grassland species is rather blurred. Some species that appear in GRIFFITH'S CHEGD checklist have been reported for both habitats, e.g. E. conferendum and E. undatum or are - according to NoORDELOOS [25] even linked to woodlands, e.g. E. lampropus. Even NITARE [20] listed E. juncinum, a species that surely has rather low requirements on its habitat; it grows "frequently under Urtica in nitrogen-rich habitats" [25: p. 246]. This bivalence with regard to the habitat (woodland vs. grassland) has been observed for other members of the CHEGD taxa as well, e.g. for species of the Clavariaceae [26, 27] Hygrocybe s.1. [3, 28] and Microglossum spp. belonging to Geoglossaceae [29, 30]. In the genus Entoloma, all species from the subgenera Leptonia and Trichopilus as well as some from the subgenus Nolanea are regarded as grassland dwellers $[25,31]$. In the future, however, a comprehensive list of grassland species will be needed to ensure the correct interpretation of CHEGD lists.

A total of 33 Entoloma species have been recorded in the Gottesacker graveyard in recent decades, but only 23 can be considered praticolous and of these, again, two recorded taxa should be labeled "dubious", namely E. favrei and E. pseudoturci. The first taxon will probably have to be included into E. clandestinum s.s. Already LUDWIG [32] reclassified E. papillatum under E. clandestinum. This was later approved by molecular studies by 
KOKKONEN [33], who included E. kerocarpus, as well. We collected some specimens that were determined to be $E$. favrei (mainly because of the capitate caulocystidia) but were found to belong to E. clandestinum based on the ITS sequence (data not published; compare figures $1 \mathrm{M}$ and $\mathrm{N}$ ). The second doubtful species, E. pseudoturci, was determined on the basis of morphological characters (compare figures $1 \mathrm{E}$ and $\mathrm{F}$ ), but its partial ITS-Sequence (approx. 150 bp length - data not shown) was close to that published by KOKKONEN [33] for $E$. aff. sarcitulum, a species that forms a complex with E. longistriatum and E. sarcitulum and requires further investigation.

Noteworthy is the appearance of five whitish to cream-colored species of the genus Cuphophyllus (formerly Hygrocybe), i.e. C. angustifolius, C. berkeleyi, C. borealis, C. cereopallidus, C. virgineus. While BOERTMANN [28] recognizes only the latter at the species level, other authors consider all five to be separate species [34-37]. C. borealis, however, seems to represent a dry form of $C$. virgineus, as already pointed out by HARDTKE [36] and BOERTMANN [28] and was thus marked as "dubious species" on the list.

For the time being, we include all these doubtful records in our CHEGD list, but being aware of possible taxonomic changes in the near future.

Tab. 2: Evaluation scheme for CHEGD species modified according to GRIFFITH et al. [2] and LÜDERITZ [27] with regard to records at the "Gottesacker" solely made by ZSCHIESCHANG and total records in brackets (Z./total)

\begin{tabular}{|l|c|c|c|c|c|c|}
\hline Value ranking & $\begin{array}{c}\text { Clavaria- } \\
\text { ceae }\end{array}$ & $\begin{array}{c}\text { Hygro- } \\
\text { cybe } \text { s.l. }\end{array}$ & $\begin{array}{c}\text { Entoloma } \\
\text { S.l. }\end{array}$ & $\begin{array}{c}\text { Geoglossa- } \\
\text { ceae }\end{array}$ & $\begin{array}{c}\text { Dermo- } \\
\text { loma }\end{array}$ & Sum \\
\hline 1. International & $\mathbf{8 +}(6 / 8)$ & $\begin{array}{c}15+ \\
(17 / 18)\end{array}$ & $\begin{array}{c}15+ \\
(15 / 23)\end{array}$ & $\mathbf{4 +}$ & $\mathbf{4 +}$ & $\begin{array}{c}46+ \\
(38 / 51)\end{array}$ \\
\hline 2. National & $\mathbf{5 +}$ & $\mathbf{1 0 +}$ & $\mathbf{1 0 +}$ & $\mathbf{3 +}$ & $\mathbf{3 +}$ & $\mathbf{3 1 +}$ \\
\hline 3. Regional & $\mathbf{3 +}$ & $\mathbf{7 +}$ & $\mathbf{6 +}$ & $\mathbf{2}$ & $\mathbf{2}$ & $\mathbf{2 0 +}$ \\
\hline 4. Local & $\mathbf{2}$ & $\mathbf{4 +}$ & $\mathbf{3 +}$ & $\mathbf{1}$ & $\mathbf{1}$ & $\mathbf{1 1 +}$ \\
\hline 5. Municipal & $\mathbf{1}$ & $\mathbf{2 +}$ & $\mathbf{2 +}$ & $\mathbf{1}(0 / 1)$ & $\mathbf{1}(1 / 1)$ & $\mathbf{7 +}$ \\
\hline $\begin{array}{l}\text { 6. Not deserving } \\
\text { protection }\end{array}$ & $\mathbf{0}$ & $\mathbf{0 - 1}$ & $\mathbf{0 - 1}$ & $\mathbf{0}$ & $\mathbf{0}$ & $\mathbf{0 - 2}$ \\
\hline
\end{tabular}

Source: Own

The CHEGD profile of the Gottesacker solely based on ZSCHIESCHANG'S records can be described as: C6 H17 E15 G0 D1 (in total 38 species). Updated with records post ZsCHIESCHANG, the profile is: C8 H18 E23 G1 D1 (in total 51 species). Following the evaluation-scheme of GRIFFITH et al. [2] and its modification according to LÜDERITZ [27], the Gottesacker is to be classified a grassland of international value (Table 2). In addition to the outstanding CHEGD profile, we want to point out the noteworthy records of two species, of which one, E. brunneosericeum, is new to Germany and represents - to our knowledge - the first record north of the Alps. The other remarkable species, C. messapica, is new to Saxony and represents the second record for Germany. There is another currently undescribed Entoloma sp. from the Gottesacker graveyard, which we have also found at another highvalue grassland (in the Zittau Mountains [38]), but its description is still pending.

Eventually, we would like to emphasize that the three most valuable grasslands (in terms of fungal diversity) in Upper Lusatia are "meadows" in parks, i.e. the herein described Gottesacker in Herrnhut, then a recently reported park lawn in Lückendorf $[7,15]$ and the "Azalea and Rhododendron Park Kromlau" with outstanding records of Clavria zollingeri and Hygrocybe punicea [11]. 


\section{Conclusion}

The CHEGD profile of the Gottesacker graveyard, which is based on survey-data of over 50 years, is in fact an outstanding refuge for rare fungal species and can be ranked as habitat of international importance. The two noteworthy records of $E$. brunneosericeum and $C$. messapica underline the uniqueness of this highly valuable, unimproved grassland.

\section{Acknowledgements}

The authors would like to thank Mr. FRANK DÄMMRICH (Limmbach-Oberfrohna) and Prof. em. Dr. HANS-JÜRGEN HARDTKE (Dresden) for providing data of fungal-records as well as Dr. MAtTHIAS KäNDLER (Oderwitz) for supplying climate data and Dr. Marzena Poraj-Kobjelska and Dr. Kateřina Barková for the Polish and Czech translation of the abstract, respectively.

\section{Literature}

[1] CARDINALE, B. J.; DUFFY, J. E.; GONZALEZ, A.; HOOPER, D. U.; PERRINGS, Ch.; VENAIL, P.; NARWANI, A.; MACE, G. M.; TILMAN, D.; WARDLE, D. A.; KINZIG, A. P.; DAILY, G. C.; LOREAU, M.; GRACE, J. B.; LARIGAUDERIE, A.; SRIVASTAVA, D. S.; NAEEM, S.: Biodiversity loss and its impact on humanity. Nature. DOI: 10.1038/nature11148

[2] GRIFFITH, G. W.; GAMARRA, J. G. P.; HOLDEN, E. M.; MITCHEL, D.; GRAHAM, A.; EVANS, D. A.; EVANS, S. E.; ARON, C.; NOORDELOOS, M. E.; KIRK, P. M.; SMITH, S. L. N.; WOODS, R. G.; HALE, A. D.; EASTON, G. L.; RATKOWSKY, D. A.; STEVENS, D. P.; HALBWACHS, H.: The international conservation importance of Welsh 'waxcap' grasslands. Mycosphere. DOI: $10.5943 /$ mycosphere/4/5/10

[3] HALBWACHS, H.; KARASCH, P.; GRIFFITH, G. W.: The diverse habitats of Hygrocybe - peeking into an enigmatic lifestyle. Mycosphere. DOI: $10.5943 /$ mycosphere/4/4/14

[4] HALBWACHS, H.; EASTON, G. L.; BOL, R.; HOBBIE, E. A.; GARNETT, M. H.; PERŠOH, D.; DIXON, L.; OSTLE, N.; KARASCH, P.; GRIFFITH, G.W.: Isotopic evidence of biotrophy and unusual nitrogen nutrition in soil-dwelling Hygrophoraceae. Environmental Microbiology. DOI: 10.1111/1462-2920.14327

[5] RUTHSATZ, B.: Was haben Pilze wie die Saftlinge (Gattung Hygrocybe s. 1.) auf magerem Grünland zu suchen? Tuexenia. DOI: 10.14471/2018.38.007

[6] TELlO, S. A.; SILVA-FLORES, P.; AGERER, R.; HALBWACHS, H.; BECK, A.; PERŠOH, D.: Hygrocybe virginea is a systemic endophyte of Plantago lanceolata. Mycological Progress. DOI: 10.1007/s11557-013-0928-0

[7] KARICH, A.; KELLNER, H.; SCHMIDT, M.; ULLRICH, R.: Ein bemerkenswertes Mykotop im Zittauer Gebirge mit Microglossum rufescens als Erstnachweis für Deutschland. Boletus. 2015, Vol. 36, Issue 2, pp. 151-163.

[8] DÖRFELT, H.; HEKLAU, H.: Die Geschichte der Mykologie. Einhorn-Verlag Dietenberger, Schwäbisch Gmünd, 1998. ISBN 3927654442.

[9] NCBI: GenBank. [online]. 2021. [accessed 2021-03-09]. Available from WWW: https://www.ncbi.nlm.nih.gov/ 
[10] NILSSON, R. H.; LARSSON, K.-H.; TAYLOR, A. F. S.; BENGTSSON-PALME, J.; JEPPESEN, T. S.; SCHIGEL, D.; KENNEDY, P.; PICARD, K.; GLÖCKNER, F. O.; TEDERSOO, L.; SAAR, I.; KÕLJALG, U.; ABARENKOV, K.: The UNITE database for molecular identification of fungi: handling dark taxa and parallel taxonomic classifications. Nucleic Acids Research. DOI: 10.1093/nar/gky1022

[11] DGfM: Pilze Deutschlands. [online]. 2021. [accessed 2021-03-09]. Available from WWW: http://WwW.pilze-deutschland.de/

[12] VIlA, J.; CARBÓ, J.; CABALlERO, F.; CATALÀ, S.; LLIMONA, X.; NOORDELOOS, M. E.: A first approach to the study of the genus Entoloma subgenus Nolanea s.l. using molecular and morphological data. Fungi non Delineati. 2013, Vol. 66 (Studies on Entoloma): Edizioni Candusso, Alassio. ISSN 1128-6008.

[13] DONDL, M.: Hias' Schwammerlseiten: Entoloma: Nr. 13: Entoloma brunneosericeum Noordel., Vila, F. Caball. \& E. Suárez. [online]. 2021. [accessed 2021-03-09]. Available from

WWW:

http://www.interhias.de/schwammerlseiten/bestimmungen/2014/entoloma/entoloma.htm $\underline{\text { \#ank13 }}$

[14] AGNELLO, C.; KAUTMANOVÁ, I.; CARBONE, M.: Clavaria messapica, una nuova specie del sud della Puglia. Rivista di Micologia. 2014, Vol. 3, pp. 195-210.

[15] KARICH, A.; ULLRICH, R.: Lamelloclavaria petersenii, a Clavariaceae with agaric hymenophor-First German record. Boletus. 2019, Vol. 40, Issue 1, pp. 17-23.

[16] JÜLICH, W.: Die Nichtblätterpilze, Gallertpilze und Bauchpilze. VEB Gustav Fischer Verlag, Jena, 1984. ISBN 3437202820.

[17] KNUDSEN, H.; SHIRYAEV, A. G.; KAUTMANOVÁ I.: Clavaria L.: Fr. In: Knudsen H.; Vesterholt J. (eds), Funga Nordica, $2^{\text {nd }}$ edition. 2018. ISBN 9788798396130.

[18] CORNER, E. J. H.: A Monograph of Clavaria and Allied Genera. Oxford University Press, London, 1950. ISBN 8121104602.

[19] ARNOLDS, E. J. M.: Ecology and coenology of macrofungi in grasslands and moist heathlands in Drenthe, the Netherlands. J. Cramer im AR Grantner Verlag Vaduz, 1981. ISBN 9783768213141.

[20] NITARE, J.: Jordtungor, en svampgrupp pa tillbakagang i naturligafodermarker. Svensk Botanisk Tidskrift. 1988, Vol. 82, pp. 341-368.

[21] RALD, E.: Vokshatte som indikatorarter for mykologisk vaerdifulde overdrevslokaliteter. Svampe. 1985, Vol. 11, pp. 1-9.

[22] ROTHEROE, M.: Mycological survey of selected semi-natural grasslands in Carmarthenshire. Contract Science Report No. 340. Countryside Council for Wales, Bangor, 1999.

[23] LEGON, N. W.; HENRICI, A.: Checklist of the British \& Irish Basidiomycota. Royal Botanic Gardens, Kew, 2005. ISBN 1842461214.

[24] KOBAYASHI, H.; HATANO, K.: A morphological study of the mycorrhiza of Entoloma clypeatum f. hybridum on Rosa multiflora. Mycoscience. DOI: $\underline{10.1007 / \mathrm{BF} 02463979}$

[25] NOORDELOOS, M. E.: Entoloma, s.l. (Fungi Europaei 5). Libreria editrice Giovanna Biella, Saronno, 1992. 
[26] CORNER, E. J. H.: Supplement to "A Monograph of Clavaria and allied Genera". Nova Hedwigia, Beihefte, Vol. 33, 1970. ISBN 978-3-768-25433-5.

[27] LÜDERITZ, M.: Kooperation im mykologischen Artenschutz - Hotspot auf Fehmarn entdeckt. In: Jahresbericht 2016 zur biologischen Vielfalt - Jagd- und Artenschutz. Ministerium für Energiewende, Landwirtschaft, Umwelt und ländliche Räume des Landes Schleswig Holstein, Kiel, Germany, 2016.

[28] BOERTMANN, D.: The genus Hygrocybe. $2^{\text {nd }}$ revised edition (Fungi of nordern Europe Vol. 1). Narayana Press, Roskilde, 2010. ISBN 9788798358176.

[29] KUČERA, V.; LIZOŇ, P.; TOMŠOVSKÝ, M.; KUČERA, J.; GAISLER, J.: Reevaluation of the morphological variability of Microglossum viride and M. griseoviride sp. nov. Mycologia. DOI: 10.3852/106.2.282

[30] KUČERA, V.; LIZOŇ, P.; TOMŠOVSKÝ, M.: Taxonomic divergence of the green naked-stipe members of the genus Microglossum (Helotiales). Mycologia, DOI: $\underline{10.1080 / 00275514.2016 .1274620}$

[31] NOORDELOOS, M. E.: Entoloma s.l. Supplemento. Massimo Candusso, Alassio, 2004. ISBN 9788890105746.

[32] LUDWIG, E.: Pilzkompendium, Bd. 2: Beschreibungen. Die größeren Gattungen der Agaricales mit farbigem Sporenpulver (ausgenommen Cortinariaceae). Fungicon Verlag. Berlin, 2007. ISBN 9783940316011.

[33] KOKKONEN, K.: A survey of boreal Entoloma with emphasis on the subgenus Rhodopolia. Mycological Progress. DOI: 10.1007/s11557-015-1135-y

[34] CLÉMENÇON, H.: Taxonomische und nomenklatorische Notizen zur Gattung Camarophyllus. Schweizer Zeitschrift für Pilzkunde. 1979, Vol. 57, Issue 8, pp. 113118.

[35] CLÉMENÇON, H.: Kompendium der Blätterpilze: Camarophyllus. Beihefte zur Zeitschrift für Mykologie. 1982, Vol. 4, pp. 39-56.

[36] HARDTKE, H. J.: Interessante weissliche Camarophyllus-Arten. Mykologisches Mitteilungsblatt. 1985, Vol. 28, pp. 43-46.

[37] CANDUSSO, M.: Hygrophorus s.l. (Fungi Europaei 6). Candusso Edizioni, Alassio, 1997.

[38] WHITE, T. J.; BRUNS, T.; LEE, S.; TAYLOR, J.: Amplification and direct sequencing of fungal ribosomal RNA genes for phylogenetics. In: Innis, M. A.; Gelfand, D. H.; Sninsky, J. J.; White, T. J. (eds.), PCR Protocols: A Guide to Methods and Applications. Academic Press, San Diego, 1990. pp. 315-322. DOI: 10.1016/B978-0-12-372180$\underline{8.50042-1}$

Dr. rer. nat. Alexander Karich; Dr. rer. nat. René Ullrich; Prof. Dr. rer. nat. habil.

Martin Hofrichter 


\section{HOUBOVÉ SPOLEČENSTVÍ NA HŘBITOVĚ „GOTTESACKER“ v HERRNHUTU}

(HORNÍ LUŽICE, SASKO)

„Gottesacker“ v Herrnhutu (Horní Lužice, Sasko) je hřbitovem téměř 300 let. G. Zschieschang intenzivně mapoval své houbové společenství od 60. let 20. století. Spojením jeho nálezů a nálezů jiných mykologů zde můžeme analyzovat mykologická data, která zachycují asi 55 let. Biologickou rozmanitost hub posuzujeme se zvláštním dưrazem na druhy CHEGD (Clavariaceae-Hygrocybe-Entoloma-Geoglossaceae-Dermoloma). Tyto druhy se používají v soupisech ke klasifikaci a k posouzení toho, zda si travnaté porosty zachovávají svou hodnotu. Podle námi určeného profilu CHEGD lze „Gottesacker“ zařadit k travním porostům mezinárodního významu. Dále uvádíme makroskopické a mikroskopické charakteristiky dvou vzácných druhů CHEGD: Entoloma brunneosericeum a Clavaria messapica. Jedná se o první nálezy obou druhů v Sasku (prvního jmenovaného dokonce v celém Německu).

\section{PILZLICHE BIODIVERSITÄT AUF DEM FRIEDHOF “GOTTESACKER” IN HERRNHUT (OBERLAUSITZ, SACHSEN)}

Der „Gottesacker“ in Herrnhut (Oberlausitz, Sachsen) ist seit fast 300 Jahren ein Friedhof. G. Zschieschang hatte seine Pilzgemeinschaft seit den 1960er Jahren intensiv kartiert. Indem wir seine Erkenntnisse und die anderer Mykologen zusammenführen, können wir hier mykologische Daten analysieren, die etwa 55 Jahre umfassen. Dabei behandeln wir die pilzliche Biodiversität mit besonderem Augenmerk auf den CHEGD-Arten (ClavariaceaeHygrocybe-Entoloma-Geoglossaceae-Dermoloma). Diese Arten werden im Zuge von Inventarisierungen herangezogen, um den Erhaltungswert von Grünland zu klassifizieren und $\mathrm{zu}$ bewerten. Entsprechend dem von uns ermittelten CHEGD-Profil ist der "Gottesacker" als Grünland von internationaler Bedeutung einzustufen. Darüber hinaus präsentieren wir makroskopische und mikroskopische Charakteristika von zwei seltenen CHEGD-Arten: Entoloma brunneosericeum und Clavaria messapica. Dies sind die Erstnachweise beider Arten für Deutschland bzw. Sachsen.

\section{ZBIOROWISKO GRZYBÓW NA CMENTARZU „GOTTESACKER” W HERRNHUT (GÓRNE ŁUŻYCE, SAKSONIA)}

„Gottesacker“" w mieście Herrnhut (Górne Łużyce, Saksonia) to cmentarz istniejący od ponad 300 lat. Lokalne zbiorowiska grzybów intensywnie od lat 60. XX wieku badał G. Zschieschang. Łącząc jego obserwacje $z$ obserwacjami innych mykologów, możemy analizować dane mykologiczne obejmujące okres około 55 lat. Różnorodność biologiczną grzybów oceniamy ze szczególnym uwzględnieniem gatunków CHEGD (ClavariaceaeHygrocybe-Entoloma-Geoglossaceae-Dermoloma). Te gatunki stosowane są w dokumentacji do celów klasyfikacji i oceny, czy użytki zielone zachowują swoją wartość. Na podstawie określonego przez nas profilu CHEGD, „Gottesacker“ można zaliczyć do użytków zielonych o znaczeniu międzynarodowym. Ponadto przedstawiamy makroskopowe i mikroskopowe cechy dwóch rzadkich gatunków CHEGD: Entoloma brunneosericeum i Clavaria messapica. Gatunki te po raz pierwszy zaobserwowano w Saksonii (pierwszy z nich nawet w skali całych Niemiec). 